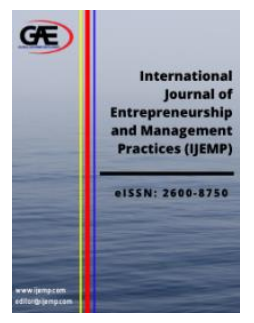

\author{
International Journal of Entrepreneurship and \\ Management Practices (IJEMP) \\ Journal Website: http://ijemp.com/ \\ eISSN: $2600-8750$
}

\title{
EMPLOYEE'S PRODUCTIVITY: THE MOST DOMINANT FACTORS
}

\author{
Noorul Huda Zakaria ${ }^{1}$, Muhazita Alias $^{2}$, Norhamimah Rani ${ }^{3}$ \\ 1 Faculty of Business Management, Universiti Teknologi Mara (UiTM) Cawangan Terengganu, Malaysia. \\ Email: noorulhuda@uitm.edu.my \\ 2 Faculty of Business Management, Universiti Teknologi Mara (UiTM) Cawangan Terengganu, Malaysia. \\ Email: muhazita@uitm.edu.my \\ 3 Academy of Language Studies, Universiti Teknologi Mara (UiTM) Cawangan Terengganu, Malaysia. \\ Email: norhamimah@uitm.edu.my
}

\section{Article Info: \\ Article history: \\ Received date:26.05.2019 \\ Revised date: 07.07.2019 \\ Accepted date: 22.01.2020 \\ Published date: 10.03.2020 \\ To cite this document:}

Zakaria, N. H., Alias, M., \& Rani, N. (2020). Employee's Productivity: The Most Dominant Factors. International Journal of Entrepreneurship and Management Practices, 3 (9), 01-13.

DOI: 10.35631/IJEMP.39001.

\begin{abstract}
:
An employee is the most important element in the success of a company. In order to achieve the optimum productivity of goods or services, the underlying factors of employee performance are very crucial to be identified. Employers should provide a conducive working environment to ensure that the employees can perform well and satisfactorily towards the success of the company. This paper, therefore, was conducted to determine the most influencing factor of employee's productivity. The aim is also to investigate the relationship between employee's productivity and three identified factors which are motivation, working environment and job satisfaction. Besides, the study also aims to examine the strategies to improve the productivity of employees. The respondents were 80 staff of Elektro Serve (M) Sdn. Bhd. (ESMSB) which is based in Paka, Terengganu. In ensuring the stability of information generated, cross-sectional data was conducted using a self-administered questionnaire. Correlation and regression analysis were conducted in analysing the data gathered. The finding shows that motivation is the most influencing factor of employee productivity followed by job satisfaction. Thus, it can be concluded that motivation and job satisfaction are the most dominant factors that contribute to the employee's productivity.
\end{abstract}

Keywords:

Employee's Productivity, Motivation, Working Environment, Job Satisfaction

\section{Introduction}

Today, most companies are not only focusing on generating income and profit, but also looking for quality management in handling and leading their employees. This is because excellent and satisfied employees will lead to high achievement and productivity of the company generally. 
Employees' productivity will not only generate internal satisfaction among them as individuals but also contribute a huge impact to the performance of the company. Haenisch (2008) in his study revealed that employees need the supervisors or the managers to improve their leadership and communication skills. Intrinsically, a manager can encourage a better production and create a more positive workplace by being understanding and communicative.

However, lack of motivation and dissatisfaction related to working environment and the nature of the job will lead to occupational stress among the employees and negative impact to the company's performance. Cincotta (2005) concluded that occupational stress level is related to employee satisfaction and motivation. Employees with high level of occupational stress have lower results on various measures of organizational effectiveness. Indirectly, it will not only affect the employees' motivation but also give drastic impact to their productivity. Employees tend to create problems in the company such as coming late to work without giving any solid reason. It will affect the working hours and the flow of the company operation. It will not only tarnish the company image but also trigger bigger problems to happen.

The working environment in the company can indeed influence the employees' productivity. The physical environment like the design and layout of the workplace may give good ambience to the employees. By being understanding, a manager can encourage a better production and create a more positive workplace. He plays a vital role to make the working environment comfortable so that employees have positive mind to stay working in the company. Thus, they will strive to be the best and deliver top-quality products and services.

Lack of job satisfaction will give negative effects to employees' productivity which contribute immensely to the failure of companies in achieving their goals. However, job satisfaction can be achieved by offering various motivating incentives to the employees which include job rotation, job enlargement and job enrichment. Chen (2008) in his study suggested that job satisfaction can be achieved by offering fair and reasonable reward to the employees. The enhancement of the promotion system and giving more opportunities to the employees to expand their career can boost their job satisfaction index. It is important to make sure that employees feel happy and satisfied with their daily work or task. If they are satisfied, they will produce a high-quality performance. Indeed, employees with high motivation who are satisfied with their working environment and job satisfaction tend to be more productive in performing their daily task.

\section{Problem Statement/Research Questions}

Employees' productivity is a vital component in assuring the achievement of the company goals and vision. It does not only contribute a huge impact to the development of an individual's career path, but also ensures that the company is able to perform and compete with its competitors. Based on the findings of the previous research, it can be concluded that the main three dominant factors known as motivation, working environment and job satisfaction contribute significantly to the employees' productivity. Motivation is one of the driving forces that has a direct impact on the business productivity as it generates the employee's willingness and determination in performing their task well. Guest (2004), Ceylan, (1998), and Silla, Gracia and Peiro (2005) concluded that working conditions have certain effects on the satisfaction of employees. The conditions include comfortable proper work and office spaces, temperature, lighting and ventilation. As mentioned by Murray (1999), job satisfaction has a direct impact on the level of presenteeism, performance and productivity. Furthermore, job satisfaction improves the retention level of employees and reduces the cost of hiring new 
employees. Based on various related issues identified, this study is designed to answer the following research questions.
i. What are the relationships between employee's productivity and motivation?
ii. What are the relationships between employee's productivity and working environment?
iii. What are the relationships between employee's productivity and job satisfaction?
iv. What are the strategies that can be implemented by the company to improve employee's productivity?

\section{Objectives of the Study}
i. To determine the most influencing factor of employee's productivity.
ii. To determine the relationship between employee's productivity and motivation.
iii. To determine the relationship between employee's productivity and working environment.
iv. To determine the relationship between employee's productivity and job satisfaction.
v. To examine the strategies to improve productivity of employees.

\section{Scope of the Study}

The focus of this research is to study the factors that contribute to the employee's productivity. The elements investigated were motivation, working environment and job satisfaction. The data used for this research was collected by using questionnaires. This research was conducted at Elektro Serve (M) Sdn. Bhd. (ESMSB) which is situated in Paka, Terengganu, Malaysia. This study focuses on staffs of support departments and production which involves 5 different departments namely the Department of Human Resources Management \& Admin, the Department of Finance and Accounts, the Department of Procurement, the Department of Contract and the Department of Operations. Under the Department of Operations, there are sub-departments such as Health, Safety \& Environment (HSE), Engineering and Production.

\section{Literature Review}

\section{Employee's productivity}

As the success of an organization relies mainly on the productivity of its employees, therefore, employee's productivity has become an important objective for businesses (Cato \& Gordon, 2009; Gummesson, 1998; Sharma \& Sharma, 2014). Previous studies have discussed the advantages of employee's productivity which would lead to overall organizational success. According to Sharma and Sharma (2014), higher productivity does not only contribute to the economic growth and higher profitability, but also in the context of social progress. This alignment, as a result, would motivate and inspire employees to be more creative, and this ultimately can improve their performance effectiveness to accomplish organizational goals and objectives (Morales, Cory \& Bozell, 2001; Obdulio, 2014). Thus, higher productivity may lead to cost reduction and able to improve the quality of output.

\section{Motivation}

Motivation is important for the employees to acquire high self-esteem. When an employee has a good motivation, the productivity will be increased. Kuvaas, Buch, Weibel, Dysvik and Nerstad (2017) in their research agreed that most motivation researchers seemed to expect that both intrinsic and extrinsic motivation would have positive effects and that the two types of motivation could be combined. Porter and Lawler (1968), drawing on the expectancy theory of Vroom (1964), proposed that intrinsic and extrinsic motivation jointly and positively predicted 
work performance and employee well-being. In addition, intrinsic motivation was positively associated with enthusiasm and engagement (Van den Broeck, De Witte \& Van Coillie, 2013). Akintoye (2000) asserted that money remained the most significant motivational strategy. He referred to the insights of Frederick Taylor and his scientific management associate who described money as the most important factor in motivating the industrial workers to achieve greater productivity. Money possesses significant motivating power as much as it symbolizes intangible goals like security, power, prestige, and the feeling of accomplishment and achievement.

Sinclair, Tucker, Cullen and Wright (2005) highlighted the motivational power of money through the process of job choice. Higher salaries and compensation benefits might seem the most likely ways to improve employee's skills (Leblebici, 2012). However, the quality of the physical workplace environment might also have a strong influence on a company's performance. Certain problems of inadequate motivation however did arise as they concerned certain individuals who came into the work situation with differences in expectation, behavior and outlook. Managers could stimulate motivation by giving relevant information on the consequences of their actions on others (Olajide, 2000). As employers or managers, they must ensure that their teams were well motivated by not only giving the employees a good job package but also words of encouragement. This could help them to move forward and boost their motivation. Innovative ways of motivating them spurred them even more. The management that dictated how, exactly, to maximize employee's productivity focused on two major areas: personal motivation and the infrastructure of the work environment. Employees were motivated and felt valued when they were given positive reinforcement and shown how their work contributes to the success of the company.

\section{Working Environment}

The employees need to work in a good environment to make sure high productivity is achieved. Organizational environment plays an important role for the employees. Working environment could impact immensely on employees' performance both negatively and positively (Chandrasekar, 2011). Office environment can be described as physical and behavioural components that can be divided into different independent variables. An organizational physical environment and its design and layout can affect employees' behavior in the workplace. In studying the impact of indoor environment, Roelofsen (2002) found that it had a great impact on job performance that can be increased from 5 to 15 percent. Workplace level also impacted on employees' stress as stated by Vischer (2006). A good working environment would lead the employees to improve their behavior and stress related emotions. Arokiasamy (2013) found that factors like compensation, rewards, job security and working environment increased the level of commitment and sense of belonging to the organization. Noah and Steve (2012) found that a working environment in an organization increased the level of job satisfaction that ultimately led to achievement of organization goals. The manager played a vital role to make the working environment comfortable for the employees to stay working in an organization. Yasin (2013) found that the productivity of employees would increase by keeping working conditions and working environment up to a certain threshold level.

\section{Job Satisfaction}

According to Miller and Monge (1986), job satisfaction increased productivity through bringing high quality motivation and increasing working capabilities at the time of implementation. A study of Judge and Watnabe (1993) suggested that job satisfaction and life satisfaction were positively and reciprocally related. Ostroff (1992) found that organizations with more satisfied employees tended to be more effective than organizations with dissatisfied 
employees. A research of Chandrasekar (2011) found a positive correlation between job satisfaction and organizational performance. Kuria (2011) highlighted that employees were mostly satisfied and highly productive when their job offerred them security from economic strain, recognition of their effort clean policy of grievances, opportunity to contribute ideas and suggestions, participation in decision making and managing the affairs, clean definitions of duties and responsibilities and opportunities for promotion, fringe benefits, sound payment structure, incentive plans and profit sharing activities, health and safety measures, social security, compensation, communication, communication system and finally, atmosphere of mutual trust respect.

\section{Methodology}

\section{Theoretical Framework}

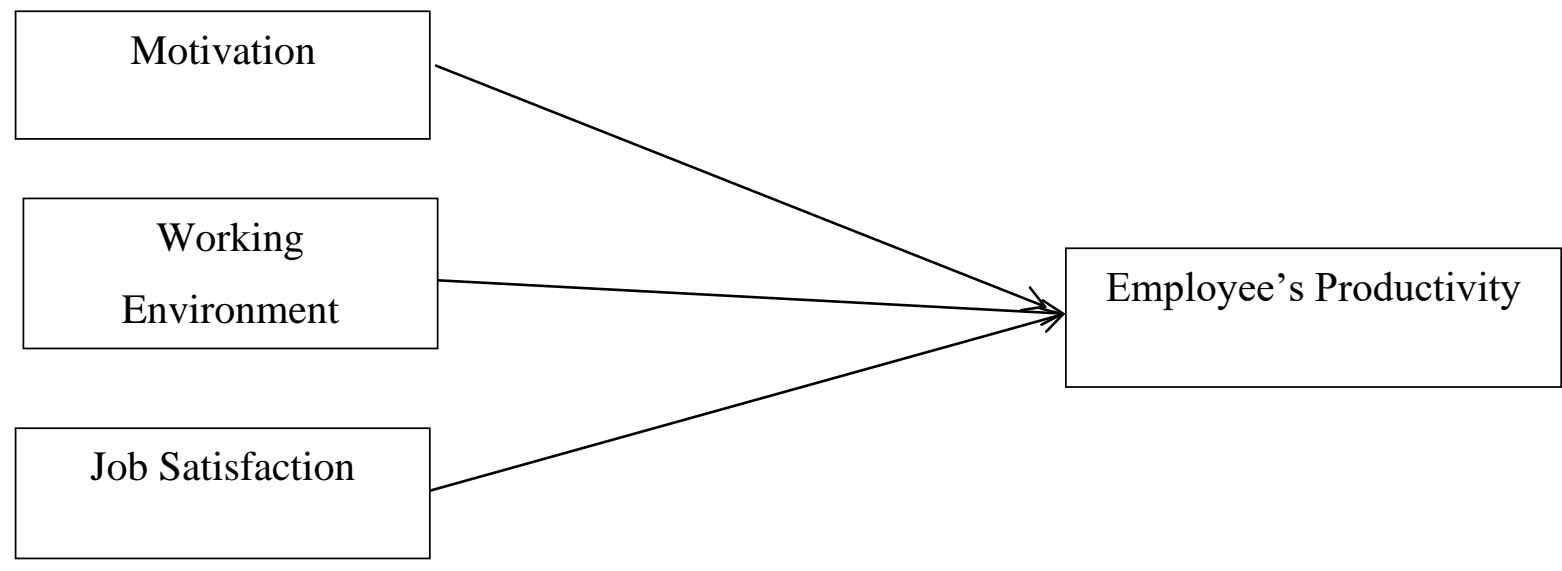

Figure 1: Theoretical Framework of the Study

\section{Hypothesis Development}

Based on the review of related literature, this study develops a few main hypotheses as listed below:

\section{Hypothesis 1: Motivation}

Ho: There is no relationship between motivation and employee's productivity.

H1: There is a positive relationship between motivation and employee's productivity.

\section{Hypothesis 2: Working Environment}

Ho: There is no relationship between working environment and employee's productivity.

$\mathrm{H} 2$ : There is a positive relationship between working environment and employee's productivity.

\section{Hypothesis 3: Job Satisfaction}

Ho: There is no relationship between job satisfaction and employee's productivity.

H3: There is a positive relationship between job satisfaction and employee's productivity. 


\section{Sampling Design}

Sampling is the procedure of deciding people and organizations from a population to be examined so that a researcher may fairly specify the results back to the population from which they were chosen. A sample is corresponding to a larger population and is used to draw a conclusion about that population. It is a research technique widely used in social science disciplines as a method to collect information about a population without having to measure the entire population. A wide range of methods in sampling techniques enable researchers to reduce the data collection needed. The data from subgroups will represent the data of each group investigated. This technique will help the researchers to reduce the time taken for the data collection. In this study, the researchers used probability techniques as the population was known in the organization. Stratified sampling method was used. According to Krejice and Morgan (1970), if the population size (N) is 100, the sample size is 80 respondents. From the sample size, the researchers used 80 employees as respondents which comprise 5 departments in the chosen company.

\section{Finding and Analysis}

\section{Reliability Analysis}

The reliability of the measurement is established by testing both consistency and stability. Cronbach' alpha is a reliability coefficient that indicates how well the items in the set are positively correlated with one another. It is computed in terms of the average intercorrelations among the items measuring the concept. The closer Cronbach' alpha to 1 indicates the higher the internal consistency reliability is. Table 1 shows the overview of Cronbach' alpha result of the reliability test of this research. It is shown that all variables have the results of more than 0.6. In general, reliabilities less than 0.6 are poor, those in the 0.7 range are acceptable and those over 0.8 are considered good. Therefore, the entire variables which are motivation, working environment and job satisfaction are reliable to the employee's productivity.

Table 1: Reliability Testing

\begin{tabular}{cc}
\hline Variables & Cronbach's Alpha \\
\hline Motivation & 0.856 \\
Working Environment & 0.834 \\
Job Satisfaction & 0.900 \\
Productivity of Employee & 0.851 \\
\hline
\end{tabular}

\section{Frequency Distribution}

The distribution of sample is displayed in Table 2. From the analysis, it was discovered that male employees are the major participants in this study compared to female employees. From 80 respondents, $83.8 \%$ were males and $16.3 \%$ were females. The result of the study shows that the highest category of age who contributed $47.5 \%$ was those of 31-35 years old and followed by $36.3 \%, 11.3 \%$ and $5.0 \%$ that were contributed by those of 26-30 years old, 20-25 years old and 36 years old and above respectively. Most of the employees in this company are married that contributed $78.8 \% .20 .0 \%$ were single and only $1.3 \%$ were widowed. All respondents are Malays that contributed $100 \%$. The Operation department which had the highest number of staff contributed $85.0 \%$ of the total respondents. The Departments of Contract and Human Resource and Administration contributed $6.3 \%$ and $3.8 \%$ respectively. The least number of respondents was from the Department of Finance and Procurement which contributed 2.5\%. 
The result shows most of the staff that contributed $72.5 \%$ were technical staff. The respondents who participated in this survey have already been in the company for more than 6 years representing the biggest distribution at $46.3 \%$. Meanwhile, those who have been in the company for 10 to 15 years contributed $22.5 \%$. Those who have been working less than 5 years and more than 15 years contributed $20 \%$ and $11.3 \%$ of the total respondents in this research.

Table 2: Respondent's Profile

\begin{tabular}{|c|c|c|c|}
\hline & Category & Frequency & Percent \\
\hline \multirow{2}{*}{ Gender } & Male & 67 & 83.8 \\
\hline & Female & 13 & 16.3 \\
\hline \multirow{4}{*}{ Age } & 20-25years & 9 & 11.3 \\
\hline & 26-30years & 29 & 36.3 \\
\hline & 31-35years & 38 & 47.5 \\
\hline & 36 Years and Above & 4 & 5.0 \\
\hline \multirow{3}{*}{ Marital Status } & Single & 16 & 20.0 \\
\hline & Married & 63 & 78.8 \\
\hline & Widowed & 1 & 1.3 \\
\hline Race & Malay & 80 & 100.0 \\
\hline \multirow{5}{*}{ Department } & $\begin{array}{c}\text { Human Resource } \\
\text { \&Admin }\end{array}$ & 3 & 3.8 \\
\hline & Finance \& Accounting & 2 & 2.5 \\
\hline & Operations & 68 & 85.0 \\
\hline & Procurement & 2 & 2.5 \\
\hline & Contract & 5 & 6.3 \\
\hline \multirow{4}{*}{ Position } & Manager & 3 & 3.8 \\
\hline & Executive & 2 & 2.5 \\
\hline & Non-Executive & 17 & 21.3 \\
\hline & Technical & 58 & 72.5 \\
\hline \multirow{4}{*}{$\begin{array}{l}\text { Working } \\
\text { Experience }\end{array}$} & 1-5years & 16 & 20.0 \\
\hline & 6-10years & 37 & 46.3 \\
\hline & 10-15years & 18 & 22.5 \\
\hline & More Than 15years & 9 & 11.3 \\
\hline
\end{tabular}

\section{Mean Analysis}

Table 3: Mean Value For The Measurement Constructs

\begin{tabular}{|c|c|c|c|c|c|}
\hline & N & Minimum & Maximum & Mean & Std. Deviation \\
\hline Productivity & 80 & 2.57 & 4.71 & 3.8482 & .44329 \\
Motivation & 80 & 2.67 & 5.00 & 3.8438 & .46490 \\
Working Environment & 80 & 3.00 & 95.50 & 4.8729 & 10.27383 \\
Job Satisfaction & 80 & 2.50 & 5.00 & 3.6792 & .51747 \\
Valid N (Listwise) & 80 & & & & \\
\hline
\end{tabular}


In measuring the central tendency, mean analysis was used. Based on this analysis, the result found that the maximum value of productivity is 4.71 and the minimum value is 2.57 with the mean 3.8482. Next, the maximum value of motivation is 5.00 and the minimum is 2.67 with the mean 3.8438. Working environment has the maximum value at 95.50 and the minimum is 3.00 with the mean is at 4.8729 . Meanwhile, the maximum value of job satisfaction is 5.00 and the minimum value is 2.50 with the mean is at 3.6792. Standard deviation is used to measure the variability of the square root of variance providing an index of variability in the distribution score. The standard deviation for the variables of employee's productivity, motivation, working environment and job satisfaction are $0.44329,0.46490,10.27383$ and 0.51747 respectively.

\section{Correlation Analysis}

Table 4: Coefficients of Variables

\begin{tabular}{|l|l|l|l|l|l|l|}
\hline \multirow{2}{*}{ Model } & \multicolumn{2}{l|}{$\begin{array}{l}\text { Unstandardized } \\
\text { Coefficients }\end{array}$} & $\begin{array}{l}\text { Standardized } \\
\text { Coeffiecients }\end{array}$ & \multirow{2}{*}{ t } & \multirow{2}{*}{ Sig. } \\
\cline { 3 - 7 } & B & Std.Error & Beta & & \\
\hline 1 & (Constant) & 0.975 & 0.330 & & 2.957 & 0.004 \\
\hline & Motivation & 0.607 & 0.082 & 0.637 & 7.432 & 0.000 \\
\hline & $\begin{array}{l}\text { Working } \\
\text { Environment }\end{array}$ & -0.002 & 0.003 & -0.043 & -0.537 & 0.593 \\
\hline & Job Satisfaction & 0.149 & 0.073 & 0.174 & 2.036 & 0.045 \\
\hline
\end{tabular}

Table 4 shows the three most influencing independent variables towards the various level of employee's productivity. As motivation increases by one standard deviation, employee's productivity increases by 0.607 of a standard deviation. Working environment shows the standardized coefficients is at -0.002 , which means every unit increase in working environment is -0.002 unit decrease in employee's productivity. For job satisfaction which increases by one standard deviation, employee's productivity increases by 0.149 of standard deviation. The highest number in beta column under standardized coefficients, 0.637 shows that motivation which is the most influencing factor of employee's productivity. This is followed by job satisfaction with beta value 0.174 and working environment with beta value -0.043 .

Table 5: Correlation Analysis

\begin{tabular}{|c|c|c|c|c|c|c|}
\hline Variable & Motivation & $\begin{array}{c}\text { Working } \\
\text { Environ } \\
\text { ment }\end{array}$ & $\begin{array}{c}\text { Job } \\
\text { Satisfaction }\end{array}$ & Productivity & Mean & $\begin{array}{c}\text { Std. } \\
\text { Deviation }\end{array}$ \\
\hline Motivation & 1 & 1 & & & 3.8438 & 0.46490 \\
\hline $\begin{array}{c}\text { Working } \\
\text { Environment }\end{array}$ & -0.063 & 1 & & 4.8729 & 10.27383 \\
\hline $\begin{array}{c}\text { Job } \\
\text { Satisfaction }\end{array}$ & $0.379^{* *}$ & 0.000 & 1 & & 3.6792 & 0.51747 \\
\hline Productivity & $0.705^{* *}$ & -0.083 & $0.416^{* *}$ & 1 & 3.8482 & 0.44329 \\
\hline
\end{tabular}


Table 5 shows the correlation analysis to test the relationship, direction and the strength of association between variables to elaborate more on inter-relation between those variables. Only two variables that are motivation and job satisfaction have positive correlations with employee's productivity. On the contrary, working environment has negative correlation with employee's productivity. Table 6 shows the degree of the relationships of the variables. The tolerance value more than 0.1 means that there are no duplications for each variable as there was no confusion between variables.

\begin{tabular}{|c|c|}
\hline \multicolumn{2}{c}{ Table 6: Correlation Strength Based on Guilford's Law } \\
\hline $\mathbf{R}$ & Strength of relationship \\
\hline$<0.20$ & Almost negligible relationship \\
\hline $0.20-0.40$ & Low correlation; definite but small relationship \\
\hline $0.40-0.70$ & Moderate correlation; substantial relationship \\
\hline $0.70-0.90$ & High correlation; marked relationship \\
\hline$>0.90$ & Very high correlation; very dependable relationship \\
\hline
\end{tabular}

Table 6 shows the correlation analysis and the strength of association between variables. It is used to trace the mutual influence of variables on one another. The result shows that motivation has a high correlation $(p=0.705)$ which is definite but marks relationship with employee's productivity. However, it has a significant relationship at the 0.01 level. Meanwhile the result has shown that there is an insignificant negative relationship correlation $(p=-0.083)$. The result is not significant because it is below 0.01 . Working environment is not related to employee's productivity because some of the employees were not affected with the working environment. They often went outstation and were not interested in working environment. The nature of business industry also influences the working environment because the staff that handle clients always have different clients and different services.

\section{Regression Analysis}

Multi-regression is an extension of bivariate correlation. Regression analysis is used to measure how many percentages of dependent variables can be explained by independent variables. It represents the best prediction of dependent variables from independent variables.

Table 7: Model Summary

\begin{tabular}{|l|l|l|l|l|}
\hline Model & $\mathbf{R}$ & R Square & Adjusted R Square & Std. Error of the Estimate \\
\hline 1 & $.725^{\mathrm{a}}$ & .525 & .506 & .31152 \\
\hline
\end{tabular}

a. Predictors: (Constant), JOB SATISFACTION, WORKING ENVIRONMENT, MOTIVATION

\section{b. Dependent Variable: PRODUCTIVITY}

Based on the table of model summary, it shows a standard multi regression analysis which was conducted to evaluate motivation, working environment and job satisfaction. The multi correlation coefficient was at 0.725 . The three independent variables which are motivation, working environment and job satisfaction explained 51 percent of the variance in competitive 
performance. This is indicated by the value of adjusted $\mathrm{R}$ square, while another 49 percent of employee's productivity was not explained by the variables.

R-Square is the proportion of variance in the dependent variable (employee's productivity) which can be predicted from the independent variables (motivation, working environment and job satisfaction). It indicates that $52.5 \%$ of the variance in employee's productivity can be predicted from the variables of motivation, working environment and job satisfaction. The remaining $47.5 \%$ of the model can be explained by other factors. R-Square is also called the coefficient of determination. The $\mathrm{R}$ value in the table is the multiple correlation coefficients between all predictor variables and the dependent variable. In this model, the value $72.5 \%$, indicates that there is a deal of variance shared by the independent variables and the dependent variable.

\section{Conclusion}

It can be concluded that not all the objectives of the study can be achieved. However, the main objective of the study which is to determine the most influencing factor in employee's productivity is achieved. The finding shows that motivation is the most influencing factor of employee's productivity followed by job satisfaction.

The second objective is to determine the relationship between employee's productivity and motivation. The study shows that motivation is an important factor that can affect employee's productivity. A motivated work force is necessary in the execution of strategies to achieve the organization goals. The employees in the company agreed that motivation, including reward and power might influence their productivity. They would perform well with the increase of their motivation level. Therefore, Hypothesis number 1 is accepted.

The third objective of this research is to determine the relationship between employee's productivity and working environment. This research shows that there is no relationship between working environment and employee's productivity. This is due to the reason that most of the employees agree that working condition is not the influencing factor that may contribute to their productivity. It is because most of the employees in the company are technical staff from operation department who work remotely from multiple locations. Therefore, they believe that it is not a major contributor. Thus, hypothesis number 2 is not accepted.

The next objective is to determine the relationship between employee's productivity and job satisfaction. The result found that most of the employees were satisfied with all systems provided by the company. They were also satisfied with the information they received from the management. The more satisfied workers with their jobs, the better the company is likely to perform to the optimum profitability and productivity. It will produce the output that may satisfy the clients and the company. Thus, hypothesis number 3 is accepted.

This research also examines strategies to improve productivity of the employees which are explained in recommendation section.

\section{Recommendation}

The result shows that poor working environment has a negative relationship with employee's productivity. Employers should create a safer working area to their employees to prevent injuries and ensure efficient job is achieved. Working environment that is equipped well will provide a better and positive atmosphere for the employees. They will feel calm in performing their tasks. Good working environment is essential in improving the company performance, 
productivity and goal achievement. Enhancing the work environment can allow the employees to attach more to the task, promote a sense of satisfaction and pleasure while improving their productivity.

One of the most vital elements in increasing employees' productivity is by enhancing a good communication among them. For instance, a clear work instruction to the employees can increase their motivation. The employer should deliver a clear explanation about the task including what the employees need to do to complete the task successfully. Therefore, the worker will do a good job because of the clear information received from the management. Employer should create a good communication channel with all employees. Two-way communication is very essential to make the information well delivered. Appreciating the ideas and listening to the employees' suggestions before deciding will acknowledge them as part of the team. Meanwhile, the company or management should create a positive and strong relationship with all employees and guide them towards task fulfilment.

Appreciation is also one of the influential factors needed by employees. When the employer appreciates their employees through recognition, they will be more motivated to perform and improve their task. As their work is valued, it will lead to productivity rise. Employees can best be motivated by giving incentives and rewards. More importantly the good work they do in the organization are appreciated and recognized.

\section{Reference}

Akintoye, I.R. (2000). The place of financial management in personnel psychology. A Paper Presented as Part of Personnel Psychology Guest Lecture Series. Department of Guidance and Counselling, University of Ibadan, Nigeria.

Arokiasamy, A. R. A. (2013). A study on employee satisfaction perspectives in the hotel industry in Malaysia. International Journal of Management and Strategy, 4(6).

Cato, S. T., \& Gordon, J. (2009). Relationship of the strategic vision alignment to employee productivity and student enrolment. Research in Higher Education Journal, 7, 1-20.

Ceylan, C., (1998). Do professional women have lower job satisfaction than professional men? Lawyers as a case study. Sex Roles. 38(7\&8): 521-537.

Chandrasekar, K. (2011). Workplace environment and its impact on organisational performance in public sector organizations. International Journal of Enterprise Computing and Business System, 1(1), 1-20.

Chen, K. (2005). Factors affecting job satisfaction of public sector employees in Taiwan. A Dissertation submitted to H. Wayne Huizange School of Business and Entrepreneurship of the Nova South-eastern University.

Cincotta, J. A. (2005). The link between occupational stress and organizational effectiveness as shown by performance evaluation, productivity measures, and employee satisfaction. A Dissertation submitted to The Faculty of the Graduate School of Education and Human Development of the George Washington University.

Guest, D. E. (2004). Flexible employment contracts, the psychological contract and employee outcomes. An analysis and review of the evidence. Int. J. Manage. Rev., 5/6 (1): 1-19.

Gummesson, E. (1998). Productivity, quality and relationship marketing in service operations. International Journal of Contemporary Hospitality Management, 10(1), 4-15.

Haenisch, J. D. (2008). Exploring and assessing factors affecting the productivity of State Government Employees. A Dissertation submitted to the Graduate Faculty of the School Business of the North Carolina University. 
Judge, T., \& Watanabe, S. (1993) Another Look at the Job Satisfaction-Life Satisfaction Relationship. Journal of Applied Psychology, 78, 939-948. http://dx.doi.org/10.1037/0021-9010.78.6.939

Krejcie, R \& Morgan, D 1970, Determining sample size for research activities. Educational and Psychological Measurement, 30, 607-610.

Kuria E. (2011). Factors influencing the level of job satisfaction of the deputy head teachers of the public secondary schools in Kenya. Un published thesis: Kenyatta University

Kuvaas, B., Buch, R., Weibel, A., Dysvik, A., \& Nerstad, C. G. L. (2017). Do intrinsic and extrinsic motivation relate differently to employee outcomes? Journal of Economic Psychology, 61. pp. 244-258.

Leblebici, D. (2012). Impact of workplace quality on employee's productivity: A case study of a bank in Turkey. Journal of Business, Economics \& Finance, 1(1): 38-49.

Miller, K. I., \& Monge, P. R. (1986). Participation, satisfaction, and productivity: a metaanalytic review. Academy of Management Journal, 29 (4): 727- 753.

Morales, C., Cory, C., \& Bozell, D. (2001). A comparative efficiency study between a live lecture and $a$ Web-based live-switched multi-camera streaming video distance learning instructional unit. Proceedings of the 2001 Information Resources Management Association International Conference, Toronto, Ontario, Canada, 63-66.

Murray, R. A., (1999). Job Satisfaction of Professional and Paraprofessional Library Staff at Chapel Hill, North Carolina. University of North Carolina at Chapel Hill.

Noah. Y., \& Steve. M. (2012). Work Environment and Job Attitude among Employees in a Nigerian Work Organization. Journal of Sustainable Society, Vol 1, No 2.

Obdulio, D. L. (2014). How management can improve corporate culture in order to have an effective work environment. Trade Publication, 75(8), 14.

Olajide, A. (2000). Getting the best out of the employees in a developing economy. A Personnel Psychology Guest Lecture Series. Department of Guidance and Counselling, University of Ibadan, Nigeria.

Ostroff, C. (1992). The relationship between satisfaction, attitudes, and performance: An organizational level analysis. Journal of Applied Psychology, 77, 963974.10.1037/0021-9010.77.6.963

Porter, L. W., \& Lawler, E. E. I. (1968). Managerial attitudes and performance. Homewood, IL: Irwin-Dorsey.

Roelofsen, P. (2002). The impact of office environments on employee performance: The design of the workplace as a strategy for productivity enhancement. Jo u r n a l of F a c i lit i e s Mana ge me $n t, 11(3)$ : 247-264.

Sharma, M. S., \& Sharma, M. V. (2014). Employee Engagement to Enhance Productivity in Current Scenario. International Journal of Commerce, Business and Management, 3(4), 595-604.

Silla, I., Gracia, F., \& Peiro, J. M. (2005). Job insecurity and health-related outcomes among different types of temporary workers. Econ. Ind. Democracy, 26: 89-117

Sinclair, R.R., Tucker, J.S., Cullen, J.C., \& Wright, C. (2005). Performance differences among four organizational commitment profiles. Journal of Applied Psychology, 90 (6), pp.1280-1287.

Van den Broeck, A., Lens, W., De Witte, H., \& Van Coillie, H. (2013). Unraveling the importance of the quantity and the quality of workers' motivation for well-being: A person-centered perspective. Journal of Vocational Behavior, 82(1), 69-78. http://dx.doi.org/10.1016/j.jvb.2012.11.005.

Vischer, J.C. (2006). The concept of workplace performance and its value to managers. California Management Review, 49(2), 62-79 
Vroom, V. H. (1964). Work and motivation. New York: Wiley.

Yassin Sheikh Ali. (2013). Working conditions and employees' productivity in manufacturing companies in Sub-Saharan African context: Case of Somalia. 2(2): 67-78. 